\title{
On the placement of the Baltic amber harvestman Gonyleptes nemastomoides Koch \& Berendt, 1854, with notes on the phylogeny of Cladonychiidae (Opiliones, Laniatores, Travunioidea)
}

\author{
Darrell Ubick $^{*, 1}$ \& Jason A. Dunlop**, 2 \\ 1 Department of Entomology, California Academy of Sciences, 875 Howard St., San Francisco, California 94103, USA \\ 2 Museum für Naturkunde der Humboldt-Universität zu Berlin, Invalidenstraße 43, D-10115 Berlin, Germany
}

Received 15 April 2004, accepted 30 May 2005

Published online 02.11.2005

With 7 figures

Key words: Arachnida, Opiliones, Laniatores, Cladonychiidae, Baltic amber, Palaeogene.

\begin{abstract}
The Baltic amber (Palaeogene: Eocene) harvestman Gonyleptes nemastomoides Koch \& Berendt, 1854 (Arachnida: Opiliones), currently misplaced at both the genus and family level, is transferred to the extant family Cladonychiidae and assigned to a new genus, Proholoscotolemon n. gen. The families Gonyleptidae and Phalangodidae are hereby removed from the known harvestman fossil record. Although the type specimen of G. nemastomoides is poorly preserved, the form of the diagnostic hind tarsal claw is clearly visible and indicates that the genus is distinct from, and relatively basal to, the only extant European cladonychiid genus, Holoscotolemon Roewer, 1915. Analysis of the claw morphology of extant cladonychiids, using evidence from ontogeny and outgroup comparison, suggests a transformation series in which the plesiomorphic condition (present in the eastern Nearctic genera Erebomaster Cope, 1872 and Theromaster Briggs, 1969) is a multi-pronged, narrowly forked claw with a long base, while the apomorphic condition (found in Holoscotolemon) is a bipronged, widely forked claw with a short base.
\end{abstract}

Schlüsselwörter: Arachnida, Opiliones, Laniatores, Cladonychiidae, Baltischer Bernstein, Paläogene.

\section{Zusammenfassung}

Der Weberknecht Gonyleptes nemastomoides Koch \& Berendt, 1854 (Arachnida: Opiliones) aus dem Baltischen Bernstein (Paläogen: Eozän) wird derzeit weder auf Gattungs- noch auf Familien-Ebene richtig zugeordnet. Er wird hiermit in die auch heute noch verbreitete Familie Cladonychiidae und die neue Gattung, Proholoscotolemon n. gen. versetzt. Für die Weberknecht-Familien Gonyleptidae und Phalangodidae gibt es somit keine fossilen Belege mehr. Obwohl das Typusexemplar von G. nemastomoides schlecht erhalten ist, ist die Form der diagnostisch wichtigen 4. Tarsalkrallen klar erkennbar. Sie zeigt an, dass die neue Gattung deutlich von der einzigen rezenten europäischen Cladonychiidae-Gattung Holoscotolemon Roewer, 1915 abweicht und im Verhältnis hierzu ursprünglicher ist. Die Analyse der Krallen-Morphologie von lebenden Cladonychiidae, bei Berücksichtigung der Ontogenie und Vergleich mit Außengruppen, deutet auf eine Entwicklungs-Reihe hin, in welcher der plesiomorphe Zustand (vorhanden in den ost-nearktischen Gattungen Erebomaster Cope, 1872 und Theromaster Briggs, 1969) durch eine schmale, mehrfach gezackte und eng gegabelte Kralle mit einer langen Basis gekennzeichnet ist. Der apomorphe Zustand (vorhanden in Holoscotolemon) ist demgegenüber eine zweizackige, breit gegabelte Kralle mit einer kurzen Basis.

\section{Introduction}

Fossil opilionids are relatively rare (see Dunlop, in press for a review), especially those of the suborder Laniatores. Three laniatorid species have been described in recent years from Dominican amber. All were assigned to extant Neotropical genera which, based on Kury (2003),

\footnotetext{
* Corresponding author: e-mail: dubick@calacademy.org

** E-mail: jason.dunlop@museum.hu-berlin.de 
currently belong either to Samoidae (Pellobunus proavus Cokendolpher, 1987 and Hummelinckiolus silhavyi Cokendolpher \& Poinar, 1998) or an incertae sedis familial position (Philacarus hispaniolensis Cokendolpher \& Poinar, 1992). There is also a tentative fossil assignment to Minuidae (Kury in Cokendolpher \& Poinar 1998). The first fossil laniatorid discovered - and the only one so far described from European Baltic amber is Gonyleptes nemastomoides Koch \& Berendt, 1854 (Fig. 1), the name having been introduced previously (Berendt 1845) as a nomen nudum without a diagnosis. As implicit in the name, the species was originally placed in the family Gonyleptidae, which is presently restricted to the South American tropics (Kury 2003). This placement was clearly not convincing because the species was immediately transferred elsewhere by Menge (1854) who, in footnotes to the original publication, suggested that G. nemastomoides be placed in Acantholophus C. L. Koch, 1839 (preoccupied, now Lacinius Thorell, 1876 - see Discussion in Crawford 1992), and later (Menge 1856 , p. 11) that it was "probably identical" to the fossil genus Cheiromachus Menge, 1854. This was a major shift in placement, because Lacinius and (probably; see Staręga 2002) Cheiromachus belong to the superfamily Phalangioidea of the "suborder" Palpatores. More than a century later, Staręga $(1976,2002)$ returned G. nemastomoides to Laniatores, but transferred it to Scoto-

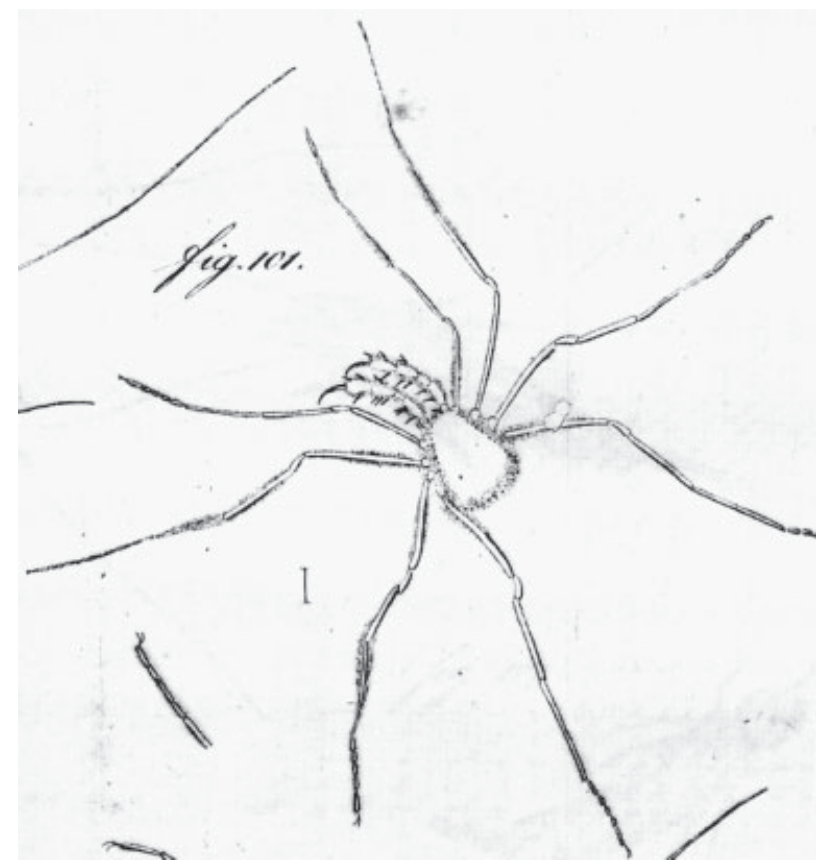

Fig. 1. Proholoscotolemon nemastomoides (Koch \& Berendt, 1854), as illustrated in fig. 101 of the original description. lemon Lucas, 1860 in the Phalangodidae. Through the courtesy of Christian Neumann we have taken the opportunity to re-examine the holotype of G. nemastomoides, which we redescribe here in a new genus belonging to the extant laniatorid family Cladonychiidae. Three further Baltic amber laniatorids which provisionally belong to this new genus are also briefly described.

\section{Material and Methods}

The holotype of Gonyleptes nemastomoides is held in the Berendt amber collection of the palaeontological department of the Museum für Naturkunde der Humboldt-Universität zu Berlin. Additional amber material, provisionally assigned to Gonyleptus, was obtained from the private collection of Jörg Wunderlich (prefix JW), Hirschberg, Germany. Specimens were examined with a Leica M420 stereo dissecting microscope and a Nikon 3-D Compound microscope, equipped with a JVC KY-F70B digital camera and a Syncroscopy Auto Montage system. Visibility of the inclusions was improved by placing a drop of glycerine on the viewing surface, topped with a cover slip. Measurements in millimetres. Amber is
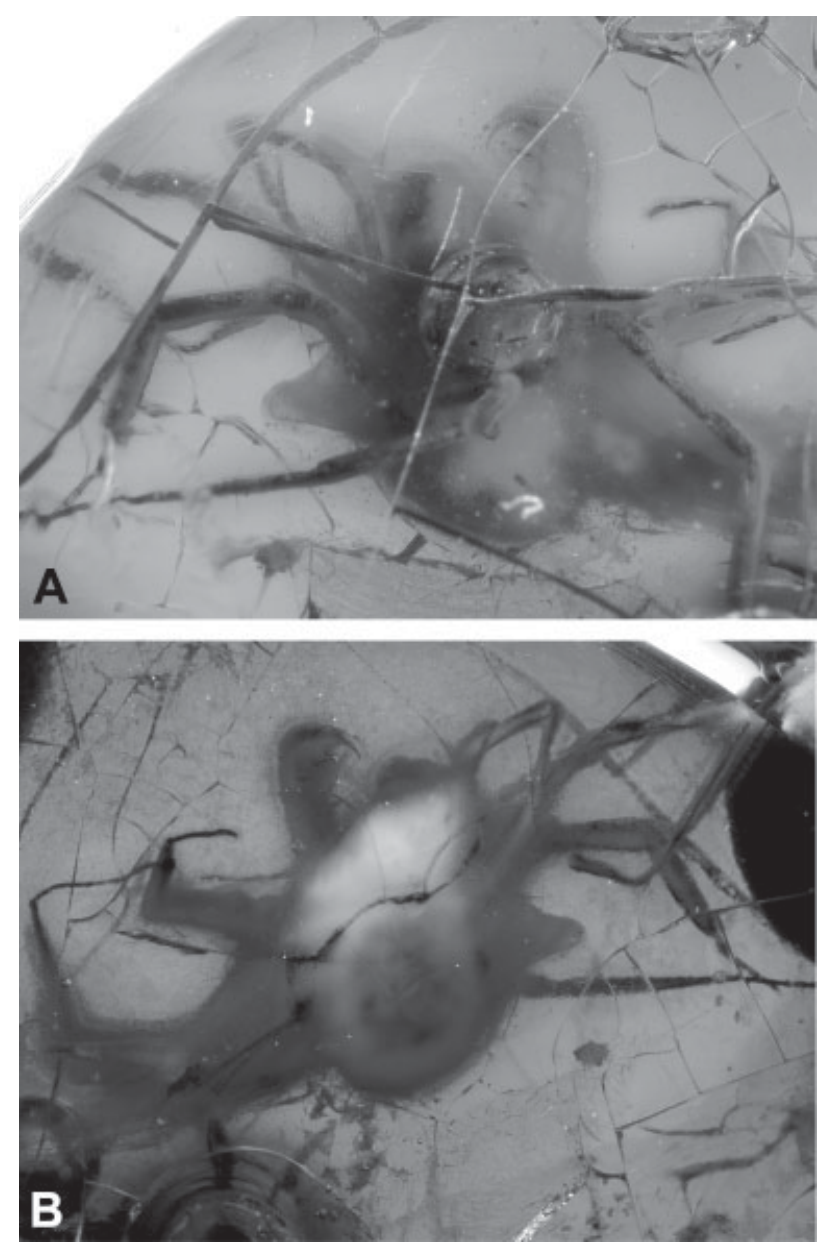

Fig. 2. Proholoscotolemon nemastomoides. Holotype: Berendt amber collection, Palaeontology Department, Museum für Naturkunde der Humboldt Universität zu Berlin. A - dorsal view; B - ventral view. 
hard to date precisely, but Baltic inclusions are generally assigned to an Eocene age, about 38-54 Ma. Extant specimens were prepared for scanning by cleaning in a Branson 1510 Ultrasonicator, dried with a Denton DCP1 Critical Point Dryer, coated with AuPd with a Denton Vacuum Desk II Sputter Coater, and examined with a Hitachi S-520 Scanning Electron Microscope.

The following extant harvestman material was examined. Cladonychiidae: Cryptomaster leviathan Briggs, 1969, Erebomaster acanthina (Crosby \& Bishop, 1924), Holoscotolemon oreophilum Martens, 1978, H. querilhaci (Lucas, 1864), H. unicolor Roewer, 1915, Speleomaster lexi Briggs, 1974 and Theromaster brunnea (Banks, 1902). Gonyleptidae: Gonyleptes saprophilus Mello-Leitão, 1922. Phalangodidae: Lola insularis Kratochvil, 1938.

\section{Morphological interpretation}

The holotype of Gonyleptus nemastomoides is an inclusion in a small piece of dark amber (Fig. 2), an oval disk about $18-20 \mathrm{~mm}$ in diameter by $2-5 \mathrm{~mm}$ thick. Little can be seen of the body and most of the appendages, which are covered by a white, powdery emulsion and a large air bubble. The ventral side is even more obscured with a large white shape covering most of the body. However, the palpi, although barely visible, do show the presence of several megaspines (Fig. 3A, B) which places the species convincingly in Laniatores and excludes the possibility that it is a phalangioid as implied by Menge (1854, 1856).

\section{Family placement}

Fortunately, the taxonomically important hind tarsal claws are clearly visible. These are bifurcate, with two prongs diverging from a common base (Fig. 3F, G). This immediately discounts the possibility that the specimen is a gonyleptid. Go-
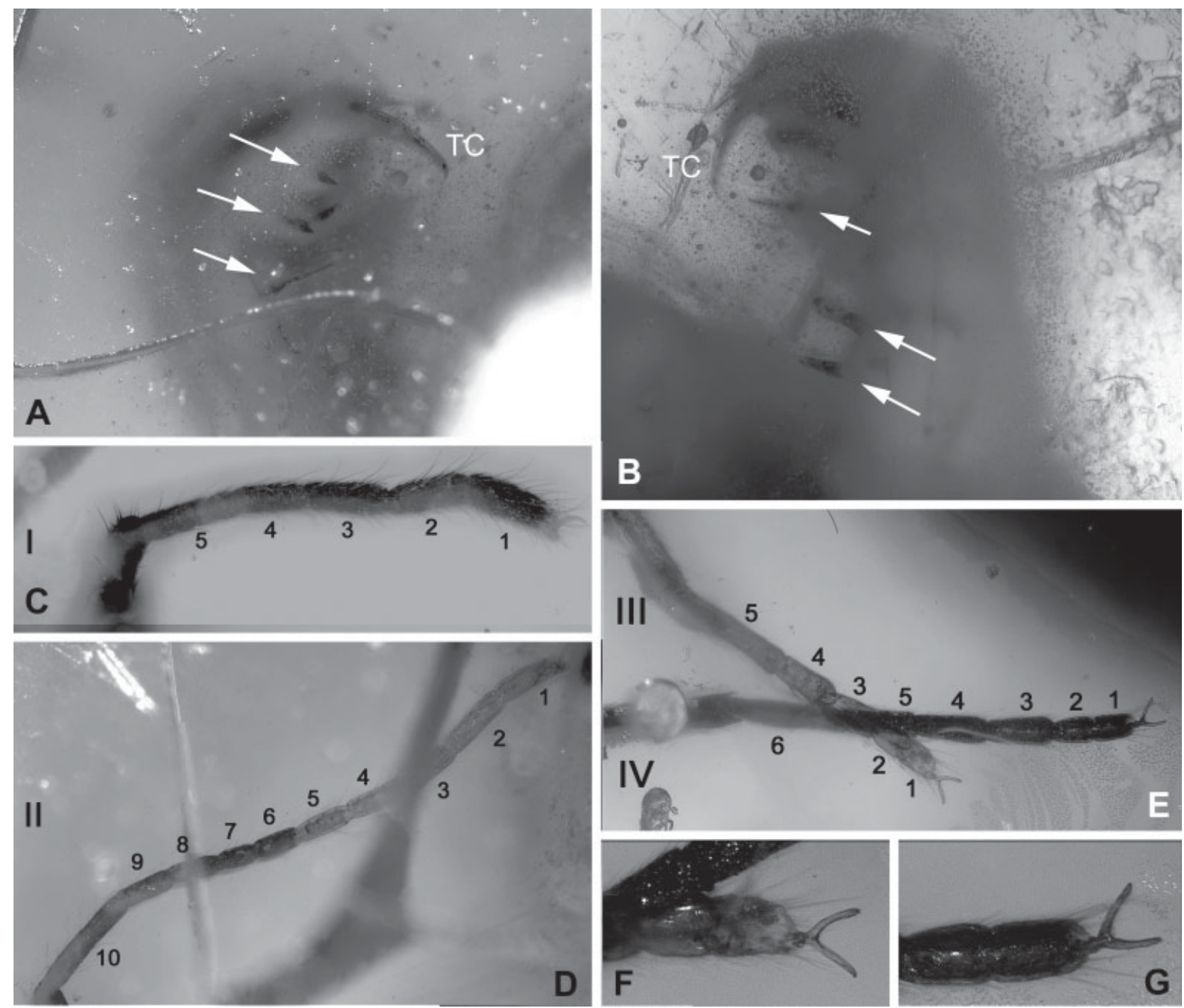

Fig. 3. Proholoscotolemon nemastomoides. Holotype. A, B - Right palpus in ventral and dorsal view. Arrows point to megaspines; TC - tarsal claw; C-G - Tarsi as viewed from ventral side of specimen; tarsomeres numbered; C - Tarsus I; D Tarsus II; E - Tarsi III and IV; F-G - Tarsi III and IV; close-up showing claws. 
nyleptidae possess a dorsal process (or pseudonychium) on the distal tarsomere (Fig. 4A, B), clearly absent in G. nemastomoides. Nor is it a member of the Phalangodidae (contra Staręga 1976, 2002), a family whose members show two separate claws on a flexible base (Fig. 4C, D). At present, bifurcate claws are known only from Cladonychiidae (Fig. 4F, G) (Briggs \& Ubick, in press). That the fossil is a cladonychiid is further supported by its relatively high tarsomere count of 5-10-5-6, which falls within the range of extant cladonychiids (having counts from 4-8-4-4 to 9-20-8-8). Note that Koch \& Berendt (1854) recorded a tarsal count of 5-10-5-5. In contrast, in phalangodids such high counts occur only in the most troglomorphic Recent species such as the European troglobites Lola insularis (4-6-5-5) and Paralola buresi Kratochvíl, 1951 (6-11-7-7). They reach no higher than 3-6-5-5 in the other phalangodid species (Ubick, in press). The relatively short legs of the fossil (Fig. 2A), clearly show that it is not strongly troglomorphic. Thus, G. nemastomoides is best accommodated in Cladonychiidae, presenting both a new family and superfamily (Travunioidea) to the fossil record. Following the present revision, Gonyleptidae and Phalangodidae have no fossil record.

\section{Generic placement}

Although the family placement of Gonyleptes nemastomoides appears clear, its generic status is less convincing. In general, the generic placement of fossil taxa is problematic, given the small window of characters visible for analysis, and is especially difficult in poorly preserved fossils such as G. nemastomoides. Until now, all but one of the amber opilionid species have been accommodated in extant genera; of the 16 genera represented in amber only the problematic Cheiromachus is strictly fossil (Dunlop, in press), the brief original description of which lacks illustrations and the repository of the type, which used to be in Danzig (= Gdansk, Poland), remains uncertain. Staręga (2002) listed the genus as ?Phalangiidae.

Given this trend to assign fossils to Recent taxa, the most obvious solution would be to include this species in the only extant European cladonychiid genus, Holoscotolemon Roewer, 1915. This genus is clearly distinguished from all other cladonychiids (four Nearctic genera) on the basis of fundamental differences in genital morphology. The condition in the Nearctic clado-
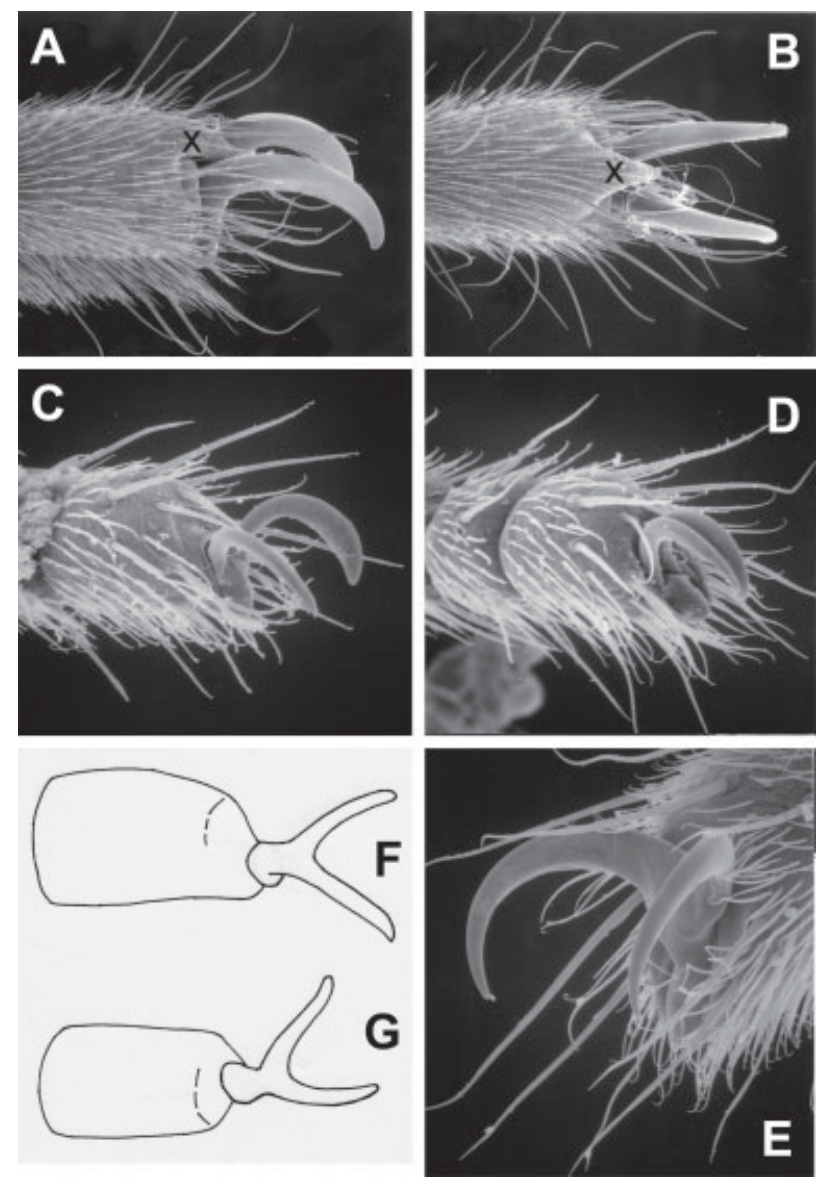

Fig. 4. Scanning electron micrographs and drawings of Recent laniatorid hind claws for comparison with the fossils. A, B Gonyleptidae (Gonyleptes saprophilus), tarsus IV, lateral and dorsal views. $\mathrm{X}=$ dorsal process (pseudonychium); $\mathbf{C}, \mathbf{D}-$ Phalangodidae (Lola insularis), tarsus IV, lateral view showing extended $(\mathbf{C})$ and retracted (D) claws. Note that retracted claws are contiguous indicating flexible attachment to base; E - Cladonychiidae (Cryptomaster leviathan), tarsus III in lateroapical view showing retracted claw. Note integral connection between claw prongs and base; F, G - Gonyleptes nemastomoides, holotype, apical tarsomeres III and IV, showing extended claws. Tarsus III (F) is a lateral view with the claw twisted giving subdorsal view. Tarsus IV (G) and claw are in subdorsal views.

nychiids, and all other travunioids except some travuniids, is that the muscles of the penis extend the entire length of the truncus; in Holoscotolemon these muscles are restricted to the base (Martens 1978: figs. 97, 103, 108, 112). However, because the genitalia are normally withdrawn in the body, these characters would not be easily (if at all) visible in a fossil. Fortunately, cladonychiid genera also differ in somatic morphology, including the form of the hind claws (Briggs 1969). Their claws differ in three characters: (1) angle of the prongs, (2) length of the claw base, and (3) presence or absence of claw spurs. Claws with the narrowest prong angle occur in the eastern Nearctic genera, Erebomaster Cope, 1872 (Fig. 5A, B) and Theromaster Briggs, 1969 (Fig. 5C, 


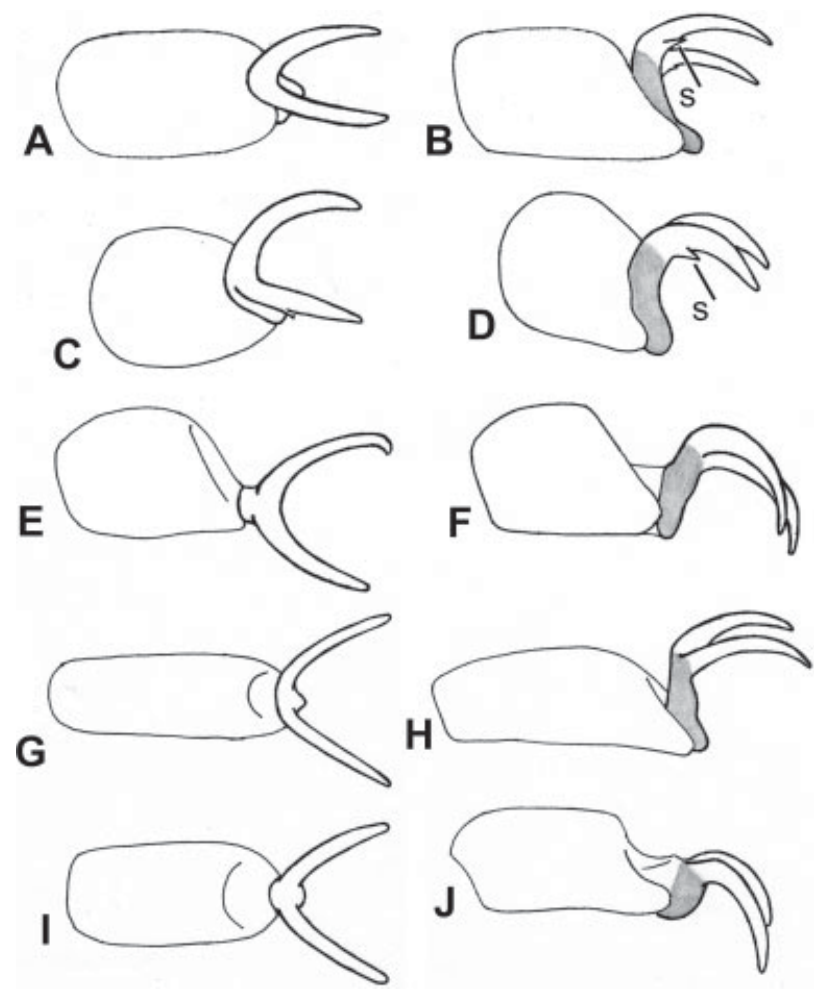

Fig. 5. Drawings of hind tarsi and claws of Recent cladonychiids. A, B - Erebomaster acanthina; $\mathbf{C}, \mathbf{D}-$ Theromaster brunnea; $\mathbf{E}, \mathbf{F}$ - Cryptomaster leviathan; $\mathbf{G}, \mathbf{H}$ - Speleomaster lexi; I, J - Holoscotolemon unicolor. Left column gives dorsal views of claws, right column, lateral views. Shaded region in lateral views indicates the extent of the claw base; $\mathbf{s}$ - claw spur.

d), and are more widely spaced in the other genera (Fig. 5E-J). The claw base is relatively long in the four Nearctic genera (Fig. 5A-H), but short in Holoscotolemon (Fig. 5I, J). Short lateral spurs are found on the claws of Erebomaster and Theromaster (Fig. 5A-D), but not in the other genera (Fig. 5E-J). The claws of Gonyleptes nemastomoides (Fig. 4F, G) have widely separated prongs, a relatively long base, and no apparent spurs. Surprisingly, in terms of claw base length, this European amber species resembles the living Nearctic genera more than the southern European Holoscotolemon (Fig. 5I, J). An examination of $H$. oreophilum, H. querilhaci, and H. unicolor (and consulting the published accounts of the other species) indicates that the hind claws of all Holoscotolemon have short bases. On the basis of these differences in claw morphology, a new genus, Proholoscotolemon (see below), is proposed for G. nemastomoides.

\section{Relationships}

Relationships among the cladonychiid genera have not been fully resolved (Briggs \& Ubick, in press). Viewed from the perspective of claw morphology, the genera from the eastern Nearctic, Erebomaster and Theromaster, differ fundamentally from the others in having short lateral branches on the claw (Fig. 5A-D). These branches are best interpreted as plesiomorphies. Evidence for this comes from ontogeny: juvenile instars have a greater number of claw branches than adults. This trend has been recorded in the families Triaenonychidae and Paranonychidae, in addition to Cladonychiidae (Briggs 1969, 1971, Suzuki 1975). That a multipronged claw is plesiomorphic is also suggested from outgroup comparison, since this is the most widespread condition in travunioids (see e.g. table 1 in Hunt \& Hickman 1993). This suggests that the two genera from the eastern Nearctic are basal in the family in having claw spurs: vestiges of the multipronged state. Using these genera as outgroups, the western Nearctic genera, Cryptomaster Briggs, 1969 and Speleomaster Briggs, 1974 which lack the claw branches and have widely spaced prongs, would be relatively derived. The condition in Holoscotolemon (Fig. 5I, J), a reduced claw base, would in this scheme be the most derived. This interpretation is supported by its reduced penis musculature, which is also regarded as derived (e.g. Martens 1978; Martens 1986; Hunt \& Hickman 1993). The full transformation series based on the claws can be summarized thus: base long to short, prong angles narrow to wide, and lateral branches present to absent. The Recent genera thus provisionally cluster as: (Erebomaster, Theromaster (Cryptomaster, Speleomaster (Holoscotolemon))).

The claw in Proholoscotolemon resembles that in the western Nearctic genera, but only through the symplesiomorphy of having a longer claw base. Although Cryptomaster and Speleomaster are united by a synapomorphy - a setiferous swelling on male tibia II (Briggs 1969: fig. 19) this is not visible in the fossil. However, evidence from palaeobiogeography predicts that the genus ought to cluster with the European taxon Holoscotolemon. During the Eocene the Holarctic was already divided by the spreading Atlantic Ocean, with Proholoscotolemon separated from its Nearctic counterparts. In fact, the two faunas were separate since Cretaceous times (about $130 \mathrm{Ma}$ ) (Smith et al. 1994). Given this length of time since the separation of the continents, their resident cladonychiids have had a long independent evolution. Thus, the Baltic amber species Proholoscotolemon is best interpreted as either the ancestor of Holoscotolemon or its sister group. 


\section{Additional amber material}

Three additional specimens in Baltic amber from the Wunderlich collection were also examined. These are clearly cladonychiids, showing bifurcate tarsal claws (with the long claw base visible in one specimen) and a palpal femur with dorsal tubercles, also characteristic of this family. These may represent Proholoscotolemon (see Systematic Palaeontology) assuming only one cladonychiid genus existed at the time. More tentative still would be assigning them to $P$. nemastomoides, especially since species identification relies heavily on characters of the male genitalia, which are typically retracted in the body. Despite these limitations, the specimens are still useful because they add to the general description of Baltic era cladonychiids, if not necessarily to Proholoscotolemon nemastomoides.

A composite description of the three specimens gives a body length from 1.9 to $3.0 \mathrm{~mm}$. Eyes are present on a low eyemound (Fig. 6C), similar to that in Holoscotolemon and Cryptomaster. The palpal femur has only one mesodistal megaspine (Fig. 6C), the condition found in Holoscotolemon, but not the Nearctic genera, which have two such spines. Also similar to $\mathrm{Ho}$ loscotolemon is the presence of two dorsal tubercles on the basal cheliceral segment (Fig. 6C).

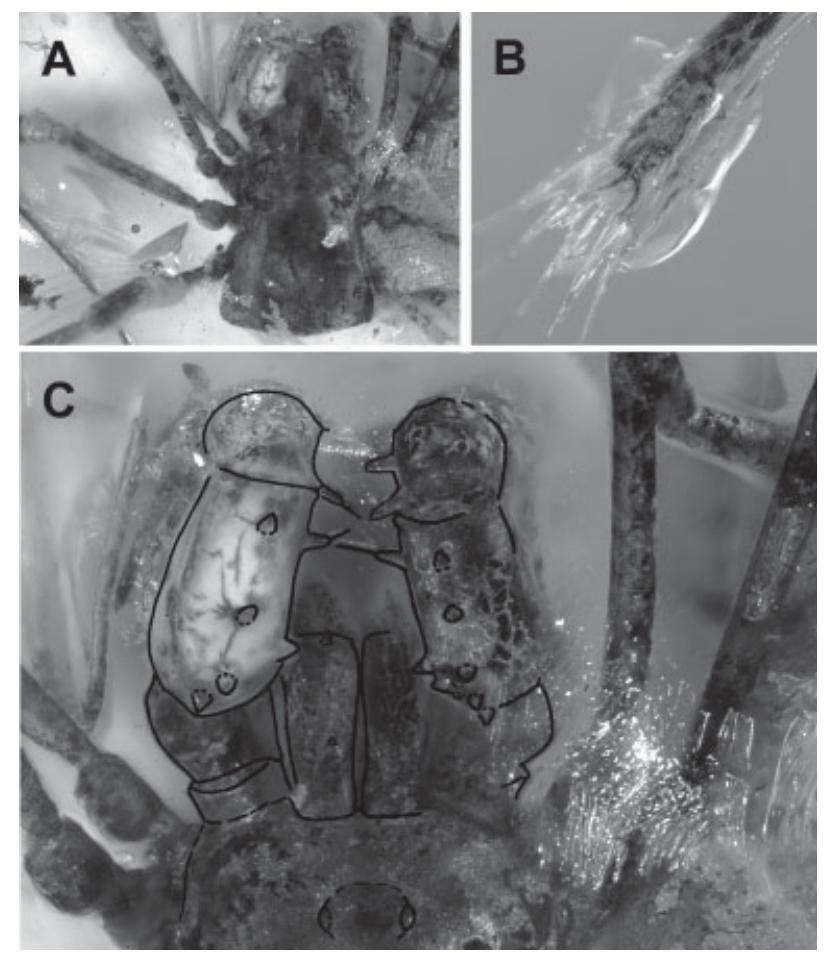

Fig. 6. Baltic amber cladonychiid, possibly Proholoscotolemon (JW866). A - Body dorsal view; B - Tarsus III or IV, dorsolateral view; C - Anterior body region, dorsal view, with interpretation of anatomy.
The condition in the Nearctic genera varies from the absence of such tubercles (Erebomaster and Theromaster) to the presence of several tubercles. Additionally, the tubercles in these fossil cladonychiids are dissimilar in size, with the anterior larger and similar to the state in $H$. querilha$c i$ (DU, pers. obs.).

\section{Biogeography}

The present-day distribution of cladonychiids in Europe is in three disjunct pockets: (1) southern France, (2) northern Italy to Hungary, and (3) Romania to Montenegro. The amber deposits bearing Proholoscotolemon are considerably farther north; even allowing for a slight northward drift of Europe since the Eocene. This is a common distribution pattern; for example Dunlop \& Giribet's (2003) Baltic amber cyphophthalmid harvestman comes from a more northerly locality than the present-day distribution of the group in Europe and suggests a warmer palaeoclimate at the time of the amber forests. Indeed, numerous studies have shown that the climate of this period was both warmer and more humid than at present (Weitschat \& Wichard 2002).

\section{Systematic palaeontology}

Suborder Laniatores Thorell, 1876

Superfamily Travunioidea Absolon \& Kratochvil, 1932

Family Cladonychiidae Hadži, 1935

\section{Proholoscotolemon n. gen.}

Type and only species: Gonyleptes nemastomoides Koch \& Berendt, 1854.

Derivation of name: The generic name is a combination of pro, Latin for earlier, and Holoscotolemon.

Diagnosis: Cladonychiid differing from Holoscotolemon in having hind claws with a longer base and the prongs set at an angle of less than $90^{\circ}$.

\section{Proholoscotolemon nemastomoides (Koch \& Berendt, 1854) n. comb.}

Figs 1-3, 4F, G

1845 Gonyleptes nemastomoides Berendt: 872. [nomen nudum]

1854 Gonyleptes nemastomoides Koch \& Berendt: 102, pl. 12 , fig. 101 
1854 Acantholophus nemastomoides. - Menge, in Koch \& Berendt: 102.

1856 ?Cheiromachus nemastomoides. - Menge: 11.

1891 Gonyleptes nemastomoides. - Scudder: 267.

1891 Acantholophus nemastomoides. - Scudder: 246.

1955 Gonyleptes nemastomoides. - Petrunkevitch: 86.

1962 Gonyleptes nemastomoides. - Dubinin: 481, fig. 1378.

1976 Scotolemon nemastomoides. - Starega: 44.

1982 Gonoleptus [sic] nemastomoides. - Cokendolpher \& Cokendolpher: 1213.

1982 Acantholophus nemastomoides. - Keilbach: 190.

1992 Gonyleptes nemastomoides. - Selden: 306.

1993 Gonyleptus nemastomoides. - Spahr: 21.

1993 ?Scotolemon nemastomoides. - Spahr: 22-23.

2002 Gonyleptes nemastomoides. - Weitschat \& Wichard: 62.

2002 Scotolemon nemastomoides. - Staręga: 603.

Holotype: Berendt amber collection. Palaeontology Department of the Museum für Naturkunde, Berlin, Germany.

Type locality and horizon: Baltic amber, locality unknown. Palaeogene: Eocene.

Diagnosis: As for the genus.

Description: Holotype specimen of unknown gender. Body length: ca. $3 \mathrm{~mm}$. Leg II longest; right palpus with 6 mesal (Fig. 3B) and 3 ectal megaspines visible (Fig. 3A); tarsi with segments and claws clearly visible (Fig. 3C-E). Tarsal count: 5-10-5-6 (Fig. 3C-E). Tarsal claws: leg I, II: single claw, undivided; leg III, IV: single claw, apically bifurcate.

\section{Proholoscotolemon sp.}

Material: Three Baltic amber specimens all from the Jörg Wunderlich collection: JW F866, F961 and F 928.

Description: "Gonyleptes-JW F866" (Fig. 6). Carapace shiny, brassy; finely rugose with larger tubercles at tergal margins. Eyemound low, rounded; posteriorly displaced from carapace margin; eyes present (Fig. 6C). Chelicerae with basal segment bearing 2 dorsal pointed tubercles, apical larger (Fig. 6C). Palpal femur with 5 dorsal tubercles (4 visible on left femur) and 1 mesal tubercle, tubercle setae not visible; megaspines: femur 1 mesoapical, patella 2 mesal. Tarsal segments: I, left 6; III, left 5, others not visible. Tarsal claw III apically bifurcate, others not visible. Measurements: Body length $1.92 \mathrm{~mm}$. Carapace length $1.86 \mathrm{~mm}$, width $1.58 \mathrm{~mm}$. Eyemound length $0.20 \mathrm{~mm}$, width $0.26 \mathrm{~mm}$. Carapace to eyemound $0.24 \mathrm{~mm}$.

"Gonyleptes-JW F961" (Fig. 7). Body brownish orange. Eyemound not clearly visible, eyes present. Ventral view clearly visible showing 5 sternites and anal operculum; genital operculum triangular, rounded (Fig. 7A). Palpal femur with 2 dorsal and 1 mesal tubercle visible; megaspines: femur 3 ventrobasal, patella 2 mesal, tibia 3 mesal, 3 ectal, tarsus 3 mesal, 3 ectal (Fig. 7B).
Tarsal segments: I, left 5; II, right ca. 12; III, left and right 4 ; IV, left 4 . Tarsal claws: I with single undivided claw; III, IV: with single bifurcate claw (Fig. 7C). Measurements: Body length $3.0 \mathrm{~mm}$. Scute length $2.5 \mathrm{~mm}$, width ca. $2.5 \mathrm{~mm}$.

"Gonyleptes-JW F928" (not figured). Eyemound low, not clearly visible. Palpal femur with 3 dorsal and 1 mesal tubercle visible; megaspines femur 2 ventral, tibia 2 ectal. Tarsal segments: I, left 4 or 5 , right 5 ; II, left ca. 10 , right damaged; III, left ca. 4; IV, missing. Tarsal claws: I, II, with single undivided claw; III, IV, not visible. Measurements: Body length $1.9 \mathrm{~mm}$. Scute length $1.6 \mathrm{~mm}$, width $1.5 \mathrm{~mm}$. Leg II length about $7.0 \mathrm{~mm}$

\section{Acknowledgements}

Thanks go to Christian Neuman (Berlin) for loaning the holotype of G. nemastomoides. Jörg Wunderlich kindly loaned three specimens from his personal collection and Jochen Martens provided extant species of Holoscotolemon for examination. James Cokendolpher and Charles Griswold provided important references and Patrick Craig supplied other valuable papers and assisted with the imaging of amber specimens. Thanks to Paul Selden and Carsten Brauckmann for providing critical reviews of this manuscript.
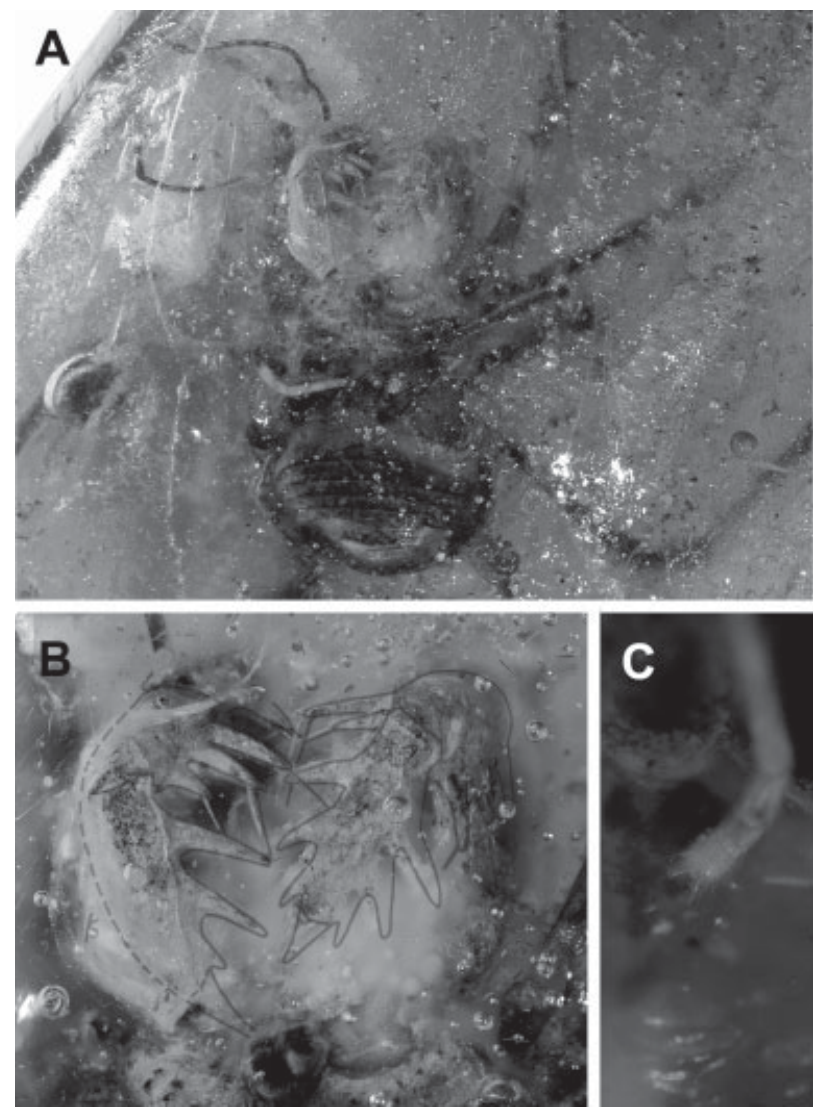

Fig. 7. Baltic amber cladonychiid, possibly Proholoscotolemon (JW961). A - Body ventral view; B - Palpi, dorsal view, with interpretation of anatomy; C - Tarsus III or IV, retracted, dorsal view. 


\section{References}

Berendt, G. C. 1845. Die im Bernstein befindlichen organischen Reste der Vorwelt, gesammelt, in Verbindung mit Mehren bearbeitet und herausgegeben. - Neues Jahrbuch für Mineralogie, Geognosie, Geologie und PetrefaktenKunde 1845: 864-879.

Briggs, T. S. 1969. A new holarctic family of laniatorid phalangids (Opiliones). - Pan-Pacific Entomologist 45: 35-50.

- 1971. Relict harvestmen from the Pacific Northwest (Opiliones). - Pan-Pacific Entomologist 47: 165-178.

Briggs, T. S. \& Ubick, D. in press. Cladonychiidae. In Pinto da Rocha, R., Machado, G. \& Giribet, G. (eds.). The Harvestmen: The Biology of Opiliones. Harvard University Press, Cambridge, MA.

Cokendolpher, J. C. 1987. A new species of fossil Pellobunus from Dominican amber (Arachnida: Opiliones: Phalangodidae). - Caribbean Journal of Science 22: 205-211.

Cokendolpher, J. C. \& Cokendolpher, J. E. 1982. Reexamination of the Tertiary harvestmen from the Florissant Formation, Colorado (Arachnida: Opiliones: Palpatores). Journal of Paleontology 56: 1213-1217.

Cokendolpher, J. C. \& Poinar Jr., G. O. 1992. Tertiary harvestmen from Dominican Republic amber (Arachnida: Opiliones: Phalangodidae). - Bulletin of the British Arachnological Society 9: $53-56$.

- 1998. A new fossil harvestman from Dominican Republic amber (Opiliones, Samoidae, Hummelinckiolus). - Journal of Arachnology 26: 9-13.

Crawford, R. L. 1992. Catalogue of the genera and type species of the harvestman superfamily Phalangioidea (Arachnida). - Burke Museum Contributions in Anthropology and Natural History 8: 1-60.

Dubinin, V. B. 1962. Klass Arachnida. Paukoobraznye. In Osnovy Paleontologii. Spravočnik dlja Paleontologov I Geologov SSSR: Členistonogii, Trachejnye I Chelicerovye (Red.: Rodendorf, B. B.): 474-517, Moskva (Akademija Nauk SSSR)

Dunlop, J. A. in press. Paleontology. In Pinto da Rocha, R., Machado, G. \& Giribet, G. (eds.). The Harvestmen: The Biology of Opiliones. Harvard University Press, Cambridge, MA.

Dunlop, J. A. \& Giribet, G. 2003. The first fossil cyphophthalmid (Arachnida, Opiliones) from Bitterfeld Amber, Germany. - Journal of Arachnology 31: 371-378.

Hunt, G. S. \& Hickman, J. L. 1993. A revision of the genus Lomanella Pocock and its implicaitons for family level classification in the Travunioidea (Arachnida: Opiliones: Triaenonychidae). - Records of the Australian Museum 45: $81-119$.

Keilbach, R. 1982. Bibliographie und Liste der Arten tierischer Einschlüsse in fossilen Harzen sowie ihrer Aufbewahrungsorte, Teil 1. - Deutsche Entomologische Zeitschrift, N. F. 29: 129-286.

Koch, C. L. \& Berendt, G. C. 1854. Die im Bernstein befindlichen Crustaceen, Myriapoden, Arachniden und Apteren der Vorwelt. In Berendt, G. C. (ed.) Die im Bernstein befindlichen organischen Reste der Vorwelt, 1, 2. 124 pp., Berlin.

Kury, A. B. 2003. Annotated catalogue of the Laniatores of the New World (Arachnida, Opiliones). - Revista Ibérica de Aracnología, Volumen especial monográfico $\mathrm{n}^{\circ} \mathbf{1}$ : $1-337$.

Martens, J. 1978. Spinnentiere, Arachnida: Weberknechte, Opiliones. Die Tierwelt Deutschlands. Vol. 64. 464 pp., Gustav Fischer Verlag, Jena.

- 1986. Die Großgliederung der Opiliones und die Evolution der Ordnung (Arachnida). In Barrientos, J. A. (ed.). - Actas X Congreso Internacional de Aracnologia (Jaca, Spain, September 1986) 1: 289-310.

Menge, A. 1854. "Bem." (Footnote on page 102). In Berendt, G. C. (ed.). Die im Bernstein befindlichen organischen Reste der Vorwelt, 1, 2. 124 pp., Berlin.

- 1856. Lebenszeichen vorweltlicher, im Bernstein eingeschlossener Thiere. Programm, womit zu der am Montag den 17. März 1856 von $81 / 2 \mathrm{Uhr}$ Vorm. und $21 / 2 \mathrm{Uhr}$ Nachm. an stattfindenden öffentlichen Prüfung der Schüller der Petrischule, 32 pp., Danzig.

Petrunkevitch, A. 1955. Arachnida. In Moore, R. C. (ed.). Treatise on Invertebrate Paleontology, Part P, Arthropoda 2. 42-162, Geological Society of America and University of Kansas Press, Lawrence, Kansas.

Scudder, S. H. 1891. Index to the known fossil insects of the world including myriapods and arachnids. - Bulletin of the United States Geological Survey 71: 1-774.

Selden, P. A. 1992. Arthropoda (Aglaspidida, Pycnogonida and Chelicerata). In Benton, M. J. (ed.). The Fossil Record 2. 297-320, Chapman \& Hall, London.

Smith, A. G., Smith, D. G. \& Funnell, B. M. 1994. Atlas of Mesozoic and Cenozoic coastlands. ix +99 pp., Cambridge University Press, Cambridge.

Spahr, U. 1993. Ergänzungen und Berichtigungen zu R. Keilbachs Bibliographie und Liste der Bernsteinfossilien Verschiedene Tiergruppen, ausgenommen Insecta und Araneae. - Stuttgarter Beiträge zur Naturkunde, Serie B (Geologie und Paläontologie) 194: 1-77.

Staręga, W. 1976. Opiliones, Kosarze (Arachnoidea). 97 pp., Polska Akademia Nauk, Warszawa.

- 2002. Baltic amber harvestmen (Opiliones) from Polish collections. - Annales Zoologici 52: 601-604.

Suzuki, S. 1975. The harvestmen of family Triaenonychidae in Japan and Korea (Travunoidea, Opiliones, Arachnida). Journal of Science of the Hiroshima University, Series B, Division 1 (Zoology) 26: 65-101.

Ubick, D. in press. Phalangodidae. In Pinto da Rocha, R., Machado, G. \& Giribet, G. (eds.). The Harvestmen: The Biology of Opiliones. Harvard University Press, Cambridge, MA.

Weitschat, W. \& W. Wichard. 2002. Atlas of plants and animals in Baltic amber. 256 pp., Verlag Dr. Friedrich Pfeil, München. 